\title{
FIRST ALCOHOL TREATMENT INSTITUTIONS IN TODAY'S CZECH REPUBLIC AND SLOVAK REPUBLIC
}

\author{
Jaroslav Šejvl, Beáta Gavurová, Miroslav Barták, Miroslava Mašlániová, Michal Miovský \\ Department of Addictology, First Faculty of Medicine, Charles University and General University Hospital in Prague, Prague, Czech Republic
}

\section{SUMMARY}

Objective: Drawing on qualitative analysis of selected historical documents, the paper seeks to provide a definition of the general characteristics of the first institutional alcohol treatment facilities in today's Czech Republic and Slovakia, taking into account the historical context of the first half of the 20th century. An additional aim was to point out the importance of archival research and its contribution to understand the determinants of alcohol-related agenda and alcohol treatment.

Methods: The basic data platform was generated by analysis of historical documents pertaining to the subject matter under study and to institutional processes in different periods. The data was processed using the open coding method (as part of the grounded theory approach) and other specific methods based on the matching of data from scientific and professional literature and archives in different periods. Over 1,100 pages of text from relevant archival materials were analysed. This research is original, no such systematic analysis of historical documents on this subject matter has been conducted on such a scale with the intention of identifying the general correlates of the historical development of an alcohol-related agenda and alcohol treatment.

Results: The establishment of the first institutional facilities intended to provide treatment for alcohol dependency was based on the notion of addiction as a disease, which needs to be treated in dedicated facilities applying an individualised approach. The circumstances of the establishment of the facilities under analysis were similar. Their existence was made possible by distinguished personalities rather than a general belief and social pressure that the issue of alcohol addiction should be addressed. This also explains the fact that the occupancy of these facilities never reached their full capacity, that they were not self-reliant in economic terms, and that they did not readily resume their operation after 1945.

Conclusions: The analysis of the establishment, operation, and dissolution of these facilities at the time reveals the discontinuity in the approach to alcohol abuse and its treatment in the context of the historical development and perception of alcohol-related problems in Czech and Slovak society in the first half of the 20th century. Significant social changes occurred after 1948. New legislative instruments were used to enforce treatment based on a principle that was different from the previous approaches. The results of our study also make it possible to reveal the intensity of apparent individual and institutional motives in the process of the development of alcohol treatment in historical terms and its projection into different post-war periods. The understanding of these correlates will help in designing additional trajectories of research into the effects of social and political changes on addiction treatment and thus identifying the intensity of the historical development and its influence on the perception of addiction treatment at present. These findings will also be of great importance for a historical comparative analysis, including overlaps with the development of recent theories, and will support the emergence of new areas of study for the social sciences.

Key words: alcohol, institutional alcohol treatment, Czech Republic, Slovak Republic

Address for correspondence: J. Šejvl, Charles University, First Faculty of Medicine, Department of Addictology and General University Hospital in Prague, Apolinárská 4, 12800 Prague 2, Czech Republic. E-mail: jaroslav.sejvl@lf1.cuni.cz

https://doi.org/10.21101/cejph.a5812

\section{INTRODUCTION}

The first half of the 20th century saw the development of the first alcohol treatment facilities in today's Czech Republic and Slovakia. Their origin was related to the perspective on the harmful effects of alcohol use that was then emerging. At the time, two general approaches to alcohol use and alcohol-related problems were applied. One of them was the temperance movement and the other, which, to a great extent, explains the context of the establishment of alcohol treatment facilities, was a focus on people with alcohol dependence. In this context, alcoholism was viewed as a disease which should be treated. While such an approach can hardly be conceived in terms of public health policies as we know them today (1), the emergence of treatment facilities at the time implied values and principles which did not take full effect until the 1960s and 1970s, when alcohol-related social problems began to be addressed on a larger scale. They may also be regarded as the initial efforts to apply a public health approach in its present-day terms. According to Harris (2), alcohol has always been a controversial social issue, as demonstrated by interventions such as prohibitions, introduced in the 19th and 20th centuries. 
The above proposition is supported by Ashley and Rankin (3), who provide four historical perspectives on alcohol use and alcohol-related problems. The first is the moral and religious concept, according to which some religions and religious groups consider alcohol sinful. The second is the teetotal movement. Its proponents advocated the elimination of sin and maintenance of morals, believing that alcohol can be a problem for everybody who uses it and is the principal cause of human suffering. This concept may have inspired a number of laws adopted in various countries, as well as being responsible for these legal regulations failing to meet their moral objectives. However unsuccessful prohibition may have been, in the USA for example, health and social problems related to alcohol use diminished dramatically. This period was followed by one focusing on alcoholism. The perspective shifted from alcohol use in communities in general to a limited group of those who drank excessively. The alcoholism movement promoted the concept that alcohol was a disease, i.e. a biological condition, which prevented individuals from controlling their alcohol use without being responsible for such absence of control - because of illness. Another notion was that of social acceptability, which was based on alcohol intoxication being widely accepted. This approach represented a shift from a bad substance (the temperance movement) to bad users or alcoholics (the alcoholism movement). Historically, these concepts tended to mingle; sometimes, multiple approaches were developed in parallel.

In the 19th century societies appeared to slacken their efforts to eradicate alcohol, with alcoholism rather than alcohol consumption in general coming to the fore as an issue of concern. It is in this period of the change in paradigm that in various places in Europe the first institutions specifically concerned with the alcohol-dependent population were established. Drawing on analysis of historical documents, the article seeks to outline the general characteristics of the first institutional alcohol treatment facilities in the area under study, taking into account the circumstances that prevailed in the period. Another aim was to point out the importance of archival research for the documentation of the development of these facilities in the public health context.

\section{Alcohol Treatment and Its Global Context}

The first rational argument that immoderate drinking required medical intervention dates back to the late 18 th century. This standpoint suggested that, rather than being "God's punishment", such behaviour has its logical causes and can be rectified by human intervention (4). These propositions were published by Benjamin Rush (5) and Thomas Trotter (6), independently of each other. These two also advocated the prevention of alcohol use and, in particular, an offer of activities and rituals acting as alternatives to those associated with drinking. However, in the 19th century, their colleagues saw a solution in establishing specialised alcohol treatment facilities and gave little consideration to such ideas. The first institutions emerged in the USA in the late $1850 \mathrm{~s}$. Before long these served as a model for British physicians who transferred the concept to Europe. This initiative of the US physicians received strong support from the American Association for the Study and Cure of Inebriety, founded in 1870. In Britain, the first treatment facility was opened in 1883 in Rickmansworth, and in 1884 the British Society for the Study and Cure of Inebriety was established. From the start of the institutional treatment, the individual facilities distinguished themselves on an open/closed door basis (4). In 1849 Magnus Huss (7) published his work, in which he was the first to define excessive drinking as alcoholism (8). Room et al. (9) as well as Šejvl and Barták (1) reported that 19th-century societies were departing from the effort to eradicate alcohol by means of prohibition, with addiction to alcohol (alcoholism) rather than drinking itself becoming the central public health topic. Room (10) noted another change in the public health perspective in the late $1980 \mathrm{~s}$, when the focus on alcoholism shifted towards alcohol-related problems and alcohol control policies. In principle, this approach is still applied even today. The rationale for it is underpinned by the growing knowledge of the aetiology of alcohol and its implications for various types of conditions, including psychosocial and behavioural problems (3).

\section{Europe and Austria-Hungary}

The first institutionalised facility for the treatment of alcohol dependency in Europe was established by Father Kruse in Lintorf near Düsseldorf (then Kingdom of Prussia) in 1850. In Switzerland, similar facilities were opened in Pilgerhütte (near Basel) in 1855, in Torlax, in the Waadt Canton, in 1883, and in Ellikon an der Thur in 1889 . The first treatment facility on the territory of Austria-Hungary came into existence in 1900 in Steinhof $(11,12)$.

While in the Czech lands the anti-alcohol movement had to rely on its own initiative and financial support, the situation was better on the territory of today's Slovakia (Upper Hungary). A significant organisation which was in operation there from 1893 to the dissolution of associations in 1949 was the Blue Cross. The Slovakian Blue Cross was a part of the organisation founded by Louis-Lucien Rochat in Switzerland in 1877. In Slovakia, the association founded its own magazine, "Light" (13). Major territorial differences included the type of alcohol that caused problems: while beer, wine, and spirits, to a lesser extent, were of concern in what is now the Czech Republic, spirits represented the main problem in Slovakia.

Delbrück (14) noted that "beer seems to be one of the worst scourges of the new century - beer consumption appears to be on the rise in all countries, which, to a certain degree, may be the result of the tall story of its nutritional power". Masaryk dated the alcohol problem back to the turn of the 17th and 18th centuries, even to the times of the Thirty Years' War (1618-1648). The mediaeval notion of a pub, or the purpose it fulfilled - especially as a place to seek refreshment, replenish supplies, and stay overnight before travelling on - was not associated with so many risk factors as was the case later, part of the reason being its very limited offer of beverages: beer and wine. Spirits were not so common and were much more expensive. A major turning point was the development of the alcohol industry, which marked a wide spread of alcohol use. Industrial production of alcohol and better technological resources used to rack and transport it, in connection with a wider range of alcoholic beverages on offer, meant a reduction in its price. In the 19th century, the availability of alcohol was practically unlimited and a factor of no less significance was that "in every village, where perhaps previously there was only a church, there is a pub, and people become drinkers there out of habit" (15).

The overview in Table 1 shows that Germany and Belgium were the greatest beer consumers in 1900, while the leaders in 
Table 1. Global alcohol consumption per capita in 1900 (14)

\begin{tabular}{|l|c|c|c|c|}
\hline \multirow{2}{*}{ Country } & \multicolumn{4}{|c|}{ Per capita consumption in litres } \\
\cline { 2 - 5 } & Beer & Wine & Spirits & Pure alcohol in total \\
\hline France & 22.60 & 94.40 & 4.25 & $16.5^{*}$ \\
\hline Belgium & 182.00 & 3.20 & 4.80 & 13.40 \\
\hline Italy & no data & 952.00 & 0.80 & 13.20 \\
\hline Switzerland & 40.00 & 607.00 & 2.75 & 11.90 \\
\hline Denmark & 102.90 & 1.20 & 7.00 & 11.80 \\
\hline Germany & 1097.00 & 5.70 & 5.70 & 10.00 \\
\hline Austria-Hungary & 32.00 & 22.10 & 5.42 & 9.50 \\
\hline England & 131.80 & 1.70 & 2.43 & 9.20 \\
\hline Netherlands & 34.00 & 2.20 & 4.50 & 6.90 \\
\hline United States & 59.10 & no data & 2.96 & 6.00 \\
\hline Sweden & 27.20 & no data & 4.20 & 5.40 \\
\hline Russia & 4.60 & 3.30 & 3.00 & 3.80 \\
\hline Norway & 37.50 & no data & 1.60 & 3.30 \\
\hline
\end{tabular}

*Excluding fruit wines

wine consumption were Italy and Switzerland. There were no major differences between the countries as regards the consumption of spirits, which can also be attributed to their limited consumption in comparison to that of beer and wine.

\section{Alcohol Dependency Treatment in What is Now the Czech Republic}

The first professional treatises on the issue of alcohol published in what is now the Czech Republic date back to the beginning of the 19th century: Pjseň nowá o vžitku nepokogné kořalky w nowě na swětlo wydaná, Wytisstěná nyněgssjho roku (16) and Abhandlung vom dem Laster der Trunkenheit (17). A translation of a German book on alcohol (Poučení o pití kořalky, podle Německého sepsáno ku prospěchu národu českoslowanskému w Čechách, w Moravě a Uhrách na swětlo wydáno) (18) and Sorger's (19) doctoral thesis at Charles and Ferdinand University were published in 1838. Kořalečnj mor, aneb, Kratochwilné poučenj, proč a gak se člowěk pitj kořalky warowati má (20) and Následkowé pitj kořalky s připogenjm některých ponaučenj pro lid wenkowský (21) were published in 1840. Another dissertation, Procházka's (22) De morbis potatorum (1842), dealt with diseases suffered by drinkers. In 1899, the Bohemian Diet commissioned the Bohemian Provincial Committee to conduct a survey and report about the spread of the "liquor plague" (23). The turn of the 19th and 20th centuries saw the emergence of scholarly papers in what is now the Czech Republic which pointed out the negative public health implications of alcohol for individuals, their families, and society as a whole. They also identified the risks of social exclusion, unemployment, and other social consequences, as well as the degenerative aspects of alcohol use: "alcoholics' children are often degenerated, crippled, hemiteric, and suffering from idiotism, madness, or falling sickness" (24).

In 1905 Gustav Kabrhel established the State Association against Alcoholism in the Kingdom of Bohemia.

The effects of alcohol on human health became the focus of professional interest. The issue of alcohol began to be addressed by distinguished personalities from various scientific disciplines, including medicine, sociology, psychology, and law. "Indirectly, alcoholism increases morbidity, as the resources spent on intoxicating beverages are often lacking as far as proper food is concerned; this prevents the body from receiving nutrition, reduces resistance, and impairs performance, which, in turn, causes economic harm to, or destroys, the individual and the family" (24). Medical care began to abandon the model of alcoholism as God's punishment for vice and sin and adopt the medical notion of alcoholism as a disease. Thanks to a wide range of distinguished figures concerned with alcoholism, the issue found its way into political circles. The social and political committee of the diet submitted to the assembly for a vote five proposals which were both preventive and punitively preventive in nature with regard to public health:

- to incorporate into the compulsory school curricula education on teetotalism and provide comprehensive education for children and adolescents, as well as guaranteeing relevant training for teachers;

- to provide support for the establishment of alcohol-free pubs, restaurants, and hotels;

- to impose restrictions on dealing in bottled beer;

- to introduce legal measures to require pubs and bars to be closed on paydays and one day following paydays;

- soldiers and mariners should be educated continually about the hazards of alcohol (25).

\section{MATERIALS AND METHODS}

The origin and development of institutional alcohol treatment in the historical area of today's Czech Republic and Slovakia from 1900 to 1950 was analysed by means of archival research on the basis of specific case studies. Historical documents were identified in archives and libraries on the above-specified territory. The sources were pooled, sorted, described, and short-listed and subsequently subjected to content analysis (26). The sources were sorted according to their contextual relevance to the emergence and development of treatment approaches and facilities. The next 
stage involved the definition of basic units and categorisation. The content analysis was conducted in line with the approach proposed by Plichtová (27), in which the individual procedures were divided into interlinked phases. Various simple methods according to Miles and Huberman (28) were used for analysis. This is the first attempt to process this original archival material and subject it to such comprehensive, thorough and systematic scrutiny. More than 1,100 pages of text were analysed.

The documents were processed using open coding (drawing on the Grounded Theory method) (29). Assorted key terms were pooled into categories of meaning. The documents were categorised according to key characteristics (such as year, author, institution). To provide some structure, a timeline of salient moments was drawn up on the basis of the information obtained from the documents.

\section{Anti-alcohol Initiatives in the Early 20th Century in Today's Czech Republic and Slovakia}

The early 20th century saw a rise in the anti-alcohol movement, whose proponents also called for the establishment of a specialised institutional facility intended specifically for the treatment of individuals dependent on alcohol. As early as 1908 , Bedřich Konařík published his first scholarly texts in which he explored the notion of alcohol use as a disease and noted the need to apply a tailored approach to alcohol patients: “...where their weakness of will and inability to resist the urge to have a drink is indicative of illness - alcoholism, and the patient is referred to as alcoholic" $(12,30)$.

The professional community was clear about the fact that the existing institutions (lunatic asylums, hospitals, houses of correction, and reformatories) did not meet the requirements for the care of alcohol-dependent individuals and could offer them no specific approach such as would be necessary for their recovery. The only facility was the Šimsa sanatorium in Krč, which, however, specialised in treating nervous disorders in general and provided no alcoholic-specific approaches. Another limitation was that the sanatorium was private and the care costs had to be fully covered by the patients.

Another factor embraced by the anti-alcohol movement was the effort to encourage people from all walks of life, particularly manual workers, to change their drinking behaviour patterns. In 1910, Koňařík found inspiration for this in Kiel, where antialcohol associations, with support from the municipal authority, offered workers inexpensive coffee and milk as replacements for alcohol (31).

On his work-related travels around Germany, Konařík also visited alcohol institutions. He noted with interest how the individual treatment facilities differed in their attitudes towards patients, specifically in the degree of their trust in patients' motivation and efforts to achieve abstinence. While in the Rhineland both Catholic and Protestant treatment facilities preferred a closed-door system, verging on the detention-based principle (i.e. patients had their day structured according to a strict timetable and were required to follow rigid daily routines, with a prescribed hierarchical arrangement based on the subordination principle, without them being allowed to make independent choices about their free time and movement), treatment facilities in the north of Germany opted for the open-door system, which was based on fostering people's con- fidence and mutual trust, with a view to the fact that they needed to become independent if they were to succeed after being released from the institution (31). A typical open-door approach, based on patients being exhorted to self-reliance and autonomy, was applied in the Salem institution. There, for the first time, Konařík had the opportunity to see a large educational exhibition presenting all the phases of the prevention and treatment of alcohol dependency. The exhibition was divided into 11 independent sections, which were interlinked and built on each other:

- alcoholism (as a disease) and other alcohol-related conditions presented by means of models of internal organs showing damage caused to them by alcohol and ethanol-preserved specimens of organs of people who died because of their excessive use of alcohol (alcohol poisoning) or were diagnosed with alcoholism;

- statistical data referring to the occurrence of alcoholism and alcohol-related mortality;

- the effects of alcohol on reproduction and possible degeneration in offspring who were conceived under the influence of alcohol;

- alcoholism and school, the education of children, and the incorporation of the issue of alcoholism into the school curricula, and the risks associated with serving alcohol to children;

- alcoholism and the ability to engage in intellectual work and the risks of overestimating the effects of alcohol on intellectual work and both their quality and quantity;

- alcoholism and crime, increased level of unhealthy selfconfidence, behavioural disinhibition, impairment of natural restraint, and incitement of salacity;

- alcoholism and the nutritional quality of substances with regard to the prices of alcohol and foodstuffs (Table 2);

- alcoholism and economic issues related to productivity, injuries, morbidity, and deaths;

- alcoholism and abstinence in various cultural states;

- a pictorial section featuring motifs of alcoholism and antialcohol movements;

- information about asylums/treatment facilities for drinkers.

The above items suggest an apparently comprehensive and well-structured approach to alcoholism and its effects on a range of social domains. In addition to a great degree of interconnection between different dimensions, the explicit implications of alcoholism for macroeconomic aspects of the country were also identified. This perspective was lacking in the previously published works. These developments indicated an evident orientation towards perceiving this issue and its solution as a matter of political concern. The significance of such a shift is reflected in support for public health policies, as well as support for various

Table 2. Comparison of nutritional values of drinks worth one mark (23)

\begin{tabular}{|l|l|}
\hline \multicolumn{2}{|c|}{1 mark } \\
\hline 1 litre of milk & 1 litre of spirits \\
\hline $175 \mathrm{~g}$ of proteins & $0 \mathrm{~g}$ of proteins \\
\hline $190 \mathrm{~g}$ of fat & $0 \mathrm{~g}$ of fat \\
\hline $225 \mathrm{~g}$ of carbohydrate & $0 \mathrm{~g}$ of carbohydrate \\
\hline $0 \mathrm{~g}$ of alcohol & $330 \mathrm{~g}$ of alcohol \\
\hline
\end{tabular}


treatment facilities and their linkage with financial schemes, volunteer activities, and the development of unions and associations. With reference to Table 2, the health aspect, too, began to draw attention during that period, not only as regards the outcome phase of the influence of alcohol on an individual (degrees of inebriety and addiction), but also the way in which alcohol can affect their nutrition. As a result, various comparisons of foodstuffs and alcohol were made, aiming at creating a psychological appeal to the population by pointing out the minimal effect of the intake of alcohol in comparison to other consumables.

Konařík was impressed the most by his visit to Ellikon, a Swiss treatment facility, where he found inspiration for the general concept of the institution in Velké Kunčice. Primarily, he drew on Bosshard's and Forel's findings, which implied that it was virtually impossible for a person to rid themselves of alcohol dependency on their own. The riskiest factors for self-help home recovery included feeble will-power, weakened by prolonged alcohol use and, especially, the negative influence of the social environment. Institutional care sought to achieve the patient's long-term, ideally lifelong abstinence, which patients themselves must be motivated to achieve with encouragement from the staff of the institution. This outcome could be accomplished by a reasonable and supportive approach applied on several levels:

- to motivate and educate patients towards changes in their lifestyles, including the principles of good diet and rational eating habits based on the reasonable intake of simple but nutritious food;

- to enhance their will and self-confidence and make them see that an alcohol-free life is not only possible, but can be of better quality and more moral and satisfying; and

- to provide each individual with moral support.

The idea was to achieve the above objectives by teaching patients to lead a simple and regular way of living, which, in the institution, involved a reasonable degree of work corresponding with their physical and mental capacities, skills, and inclinations. Work was performed in the institution (house chores), but also in workshops, in the garden, and in the field. When a patient was not able to perform any work after admission, they were given a reasonable time in which to recover. Once they regained their physical strength, they became engaged in work activities.

The standard duration of the therapy was set at six months of residential treatment $(12,32)$.

It was recommended that, philosophically, treatment should be based on religious ideas and moral support.

Institutionalised patients enjoyed full service. The treatment facility was conceived in such a way as to provide a comfortable setting and make it possible for the patients to engage in a range of activities. Besides dormitories, the facility included a dining room, entertainment hall, non-smoking reading room with a library, and a writing room. The programme was designed in such a way as not to fill up the whole day but also give patients the opportunity to engage in recreational activities, pursue their hobbies, and study. The daily programme included morning and evening prayers, abstinence-oriented lectures, singing, piano and harmonium sessions, fun activities, theatrical productions, party games, letters from recovered patients being read out, and social outings.

In addition to the elaborate and well-structured system of treatment, the Ellikon facility paid special attention to factors which played a significant role after the completion of residential treatment. In this respect, relapse prevention was a major issue. This was mainly facilitated by promoting support for the patient from their family and employer. The patient's membership of a local teetotal organisation and their contact with the treatment facility was also encouraged as a no less important factor. The practice in Ellikon showed that when the director failed to write to a patient who had completed their treatment, or did not reply to their letters, such patients may have felt abandoned and lacking moral backing (32). The treatment facility also played an important role in finding a new job. It was expected that a patient in recovery should be assisted in this by their community. "An alcoholic is an ill person and the healthy must take care of him, even after he had been cured, to ensure that the illness does not recur." Specialised institutional alcohol treatment was designed specifically for alcohol-dependent people. Taking into account the structure of the staff, individuals regarded as "completely perverted and aberrant characters" were not admitted to treatment (32).

Konařík (32) suggested that it was essential to set clear rules for admitting patients and adhere strictly to such rules.

As previously noted, a number of distinguished figures in social and cultural life were involved in the growing temperance movement. One of its leading figures was Masaryk, who addressed the alcohol problem in several of his publications. "A cheerful, recreated human being - that is our task, and to achieve it, abstinence from alcohol is necessary in addition to other efforts for truly progressive ethics. In this regard, the following holds: the future belongs to the sober, that is, to those who have opted for a higher, more virtuous worldview and way of living" (15).

\section{The First Treatment Facility in Velké Kunčice: Con- text of its Establishment}

In 1908 Konařík applied for a provincial subsidy to establish an alcohol treatment facility. The application, filed with the Moravian Provincial Assembly, was turned down. Drawing on his international experience, together with other associates, he subsequently founded the Cross Association for the Establishment and Maintenance of an Alcohol Institution, as he believed that an organisation, rather than an individual, would have a better chance of receiving financial support (30). In addition to Konařík, who was its director, the company owners František Wichterle and Count Charles Sailern contributed financially to the establishment of the association (33).

When looking for premises and an area suitable for the establishment of a treatment facility, Konařík took account of Forel's and Bosshard's recommendations (ideally a rural area not far from a big town and medical services, with arable farmland and outbuildings which could provide suitable work opportunities as a treatment support factor) and the actual financial resources available to the Cross Association and the unwillingness of national institutions to provide any financial contribution in support of the opening of the institution.

\section{Velké Kunčice (1911-1915)}

A former wayside inn and later a miners's pub, renovated in the late 19th century by the Frenštát builder Alfréd Parma and referred to accordingly as the Parma Estate, was chosen as a suitable location. The treatment facility was situated three kilometres away 
from a railway station and one kilometre away from the St. Mary Magdalene church and cemetery. The sale was made on 11 May 1910. The treatment facility was designed for up to 15 patients, with future prospects of an annex and its capacity to be enlarged to accommodate up to 35 patients. The treatment facility was put into operation on 27 December 1911 and was intended for male patients only, with the duration of the inpatient treatment being set at a period from six to 12 months. The patients were allowed to leave the institution any time they wished, but if they wanted to resume treatment, they had to start anew from the beginning. There was no entitlement to admission to the institution. The aim of the inpatient treatment was permanent abstinence and a return to normal life. The treatment was based on a psycho-socio-spiritual approach, with work therapy constituting a significant component (12). "The treatment facility included two workshops - a basketweaving shop and a room where various decorative items were painted - in which work became a therapeutic corrective element used to assist alcoholics in recovery. A young man and talented self-taught painter, Ferdiš Duša, became the foreman in the shops" (34). In this facility, for the first time, inpatient alcohol treatment was covered by a health insurer. There, Konařík created his first systematic educative exhibition - Travelling Show against Drinking - inspired primarily by his visits to Kiel and Salem in 1910. Detailed information about the institution, including the treatment conditions and strategies, the funding of the institution, and its house rules, was provided by Šejvl and Miovský (35), who also discussed the implications of the Kunčice facility for further public health approaches to addiction and addicts. They agreed that "by his indisputably innovative approach, influenced especially by the Ellikon treatment facility, Konařík caused a shift in the way the professional community perceived problems brought about by alcohol. He sought to focus on addressing alcoholism in a comprehensive manner. Besides addiction treatment itself, he placed an emphasis on patients' abilities to lead an independent, full-fledged alcohol-free life. He found it sensible to promote mutual support among the patients, as well as providing support for their relatives and the community. His therapeutic approach was based on help to the ill and mutual trust. This concept contributed to the creation of the necessary foundation for the bio-psycho-socio-spiritual approach to addiction treatment as we apply it today. It is without doubt that the initial foundations for a good, systematic, and therapy-oriented approach to individuals with alcohol dependency were laid by the Cross Association and the establishment of the treatment facility in Velké Kunčice. The elaborate approaches based on the cutting-edge treatment evidence of the time were further refined in Tuchlov and Istebné nad Oravou" (35).

The treatment facility was closed down in 1915 in consequence of the Great War, as the majority of the patients were called up and any further operation of the institution was made impossible by the lack of both financial resources and food.

\section{The Tuchlov Institution in the Period of the First Republic (1923-1938)}

The Republic of Czechoslovakia and Alcohol-related Issues

With the rise of the independent Republic of Czechoslovakia, alcohol-related issues were somewhat sidelined, at least at the beginning. In 1919, the Ministry of Public Health established a working group which was commissioned to propose a treatment procedure for individuals addicted to alcohol. The alcohol institution in Velké Kunčice ceased to exist during the Great War (1915) and Dr. Šimsa's sobering-up sanatorium in Krč closed down soon after the political changes.

Forster defined three basic ardent passions which may develop into morbid manias and which need to be dealt with by means of professional help - alcoholism, debauchery, and a passion for gambling (36).

First, it was proposed that three treatment facilities - for men, women, and incurable alcoholics, respectively, should be established to treat people dependent on alcohol. However, this idea fell through, partly also because of the frequent staff turnover at the ministry (37).

In 1922, the Czechoslovak Temperance Association (CTA) was founded (38). This organisation had a major influence on approaching alcohol use as a public health phenomenon during the era of the First Republic. This was partly due to anti-alcohol sentiments aroused by the social and health problems of the population, which dated back to the beginning of the century, but manifested themselves fully in the aftermath of the Great War. During the war, alcohol consumption grew dramatically, and after the war, it was difficult to deal effectively with what had by then become a major problem. The significant advantage of the CTA at the time was that it enjoyed support from distinguished figures in political and social life, including Tomáš G. Masaryk, Edvard Beneš, Břetislav Foustka, Vilém Forster, Jaroslav Barth, Jan Šimsa, and Karol Lányi. Masaryk (15) noted that it was very important for well-known public figures and natural authorities to serve as role models, to set an example. He held that if physicians, attorneys, judges, teachers, and priests consumed alcohol, they could hardly expect ordinary people to behave otherwise.

The CTA regarded alcohol as a widespread social phenomenon and a serious social illness. It postulated the following objectives to protect and promote public health:

- to hold and coordinate educational, awareness-raising, and cultural events, to guarantee and provide professional guidance to education towards, and the promotion of, an alcohol-free life (lectures, educational meetings, courses for both the general public and the scientific community, theatrical and cinematographic shows, alcohol-free balls, and other activities);

- to publish thematic treatises, brochures, leaflets, magazines, pictures, and posters and promote and assist in establishing reading rooms and libraries specialising in anti-alcohol literature;

- to support anti-alcohol education for adults and teachers and initiate and advocate the incorporation of anti-alcohol education into school curricula;

- to develop social and hygienic activities - to promote the establishment of specialised treatment institutions and alcohol counselling facilities;

- to support the establishment of inexpensive diners, restaurants, and hotels with no alcohol on offer and an increase in the number of outlets selling milk and fruit;

- to support the manufacture and scaling-up of the sale of soft drinks;

- social engagement - involvement in the improvement of social circumstances which are conducive to alcoholism and support 
for institutions which foster the idea of promoting temperance in the nation;

- to support legislative efforts - initiation of anti-alcohol laws, measures to regulate and restrict the production of spirits which may even take the form of local bans ("the local option"), and full nationwide prohibition of the production, sale, and the import and transportation of spirits; and

- organisational activities - the establishment of anti-alcohol and teetotal organisations (38).

The pressure for the establishment of a treatment institution had grown to such a degree that the ministry decided to go ahead with the project (39).

The information about the harmfulness of alcohol was strongly underrated by the public. While nobody would publicly deny the risks posed by hard liquor, both beer and wine were considered relatively harmless. Šimsa and others warned that the danger of alcohol increases with its becoming "an inseparable companion to each event in the life of a human being. Beer has been proclaimed "liquid bread", although, in terms of nutritional value, a litre of strong Bavarian beer is an approximate equivalent of one roll. To say the least, it is foolish to feed the body with a minute amount of nutrients, obtained at high cost and mixed with toxic substances for that matter, which we can procure in intact and pure form at any time" (40). Similar arguments were also used by Konařík, who compared the content of substances in one litre of milk and one litre of alcohol (Table 2).

Alcoholism was viewed as a major risk factor for the social and personal life of the nation (40).

Using the science-popularisation approach, Šimsa, in particular, sought to disseminate alcohol-related information among the general public. He led the team of authors who produced the two-volume work Natural Treatment and a Home Doctor. Using an appropriate form, in this publication he described the effects of alcohol on the human body. He pointed out that each person might experience the influence of alcohol differently, depending on a range of other factors, such as the drinker's overall health status, the resistance of their body, their diet, and social circumstances in general. He warned that alcohol may severely impair intelligence, clarity of judgement, and overall mental capacities and that it was a strong predictor of the development of serious medical conditions and affected people's character, induced abnormal states in people, and incapacitated them for proper work by impairing their sense of responsibility. This resulted in harm which had significant implications for the life and health of the drinker and the social situation of those close to them: a higher frequency of morbidity and related lower ability to work and earn money, greater recovery-related costs, and lower ability to provide for oneself and the family. In terms of the resulting health consequences, excessive alcohol use was categorised as follows:

- every instance of drunkenness (including common episodes of intoxication) which may develop into states of pathological inebriety;

- dipsomania;

- delirium tremens;

- alcoholic paranoia;

- acute madness with hallucinations; and

- alcoholic dementia or paralysis (40).

An independent segment of public health risks that had a major influence on the establishment of the treatment facility was the point made about the association between alcohol use and highrisk sexual behaviour, especially with regard to promiscuity and sexually transmitted diseases. "Alcohol provokes sensuality, lust, and instincts. In drinkers, who are more vulnerable to illnesses, every disease, especially the venereal type, is more difficult to cure and has a more serious course; a weakened body cannot resist the infection and is more likely to contract it. Do not become misled by nonsensical arguments that moderate, i.e. reasonable drinking, can do no harm. It is always harmful, and, what is more, it incites more drinking and is a bad example for young people, who then think that drinking is about enjoying life" (40). The link between alcohol use and high-risk sexual behaviour was suggested by Vondráček and Klášterský (41), who explored the risk of the development of latent homosexuality among drinkers.

This period also experienced a change in the way the government perceived the harmfulness of alcohol. This shift in policy was reflected by the declaration of four functional areas:

- social and hygienic - the government intended to promote public health, with both the national and local authorities and physicians being formally responsible for pursuing such efforts;

- protection and promotion of social economy - these activities were intended to support the national economy and protect it from damage caused by alcohol use and address the financial issues of the population;

- social and moral - this domain relied on the influence of natural authorities, especially philosophers, teachers, priests, and lawyers, who were expected to set an example for the population; and

- cultural - involving the role of education of adolescents within the school system and further teacher training (40).

\section{Tuchlov Institution}

The Tuchlov institution was established by Edict No. 42710/ III ai 1923, issued by the Ministry of Public Health and Physical Education on 31 December 1923. The main co-founders were Břetislav Foustka and Bedřich Konařík. Other distinguished personalities who helped establish the treatment facility included Hynek Fügner (Tuchlov's patron) and the aforementioned doctor Jan Šimsa (the first attending physician there). In addition to being appointed as the manager of the treatment institution, Father Bedřich Konařík also worked there as an educator; the first patient entered treatment on 1 November 1923. As regards its capacity, the institution was intended for 50 patients (42).

Being the only professional in possession of both theoretical and practical experience with conducting institutional alcohol treatment, in Velké Kunčice, Bedřich Konařík was commissioned by the Ministry of Public Health to act as the director and manager of the Tuchlov treatment facility. Given the circumstances, the decision of the Ministry of Public Health to appoint Konařík as the manager of the treatment facility was indeed a logical step. The treatment philosophy differed from the Kunčice model. It was based on four domains - judicial, theological, pedagogical, and medical. A major difference from the approach applied in Kunčice was the first formal use of medication in treating alcohol dependency. Šimsa held the position of the in-house physician in the facility until 1933 (37). Pharmacotherapy was applied only as a supplementary supportive element of the treatment. Rather than addressing addiction, it was used to manage concomitant withdrawal symptoms, such as agitation. 
On admission to the institution, patients underwent a thorough initial medical examination. In general, only motivated patients were allowed to enter treatment; the stay in the institution was voluntary (43). It was required that patients must strictly abstain from alcohol in order to be allowed to enter treatment (42).

As in Kunčice, daily work routines and free-time activities played an important role. Work was performed outdoors (in the grounds and in the vegetable garden) and in the joinery shop, locksmith's shop, and bindery. Treatment was complemented with relaxation and physical exercise and bibliotherapy. As in Velké Kunčice, the period of residential treatment was set to last for from six to 12 months. The treatment of impecunious patients with no insurance was covered by the Ministry of Public Health. Those who were insured had the treatment services reimbursed by their insurers. It was also possible to admit self-payers. Throughout the 15 years of its existence, the institution received financial support from the Ministry of Public Health and never became totally independent in economic terms, unlike, for example, Ellikon. Each patient could freely terminate their treatment at any time. In the event of relapse, the patients were encouraged to start the treatment anew (Table 3 ).

After being discharged from the institution, the patients were recommended to engage in aftercare. This was expected to involve their joining a local teetotal organisation. Konař́k also tried to maintain contacts with all the patients who had left the institution. Where patients lived not far away from the treatment facility, he would go to visit them in person. A significant, and highly risky, factor was the patient's return to work. In the event of a patient acquiring a new professional qualification during their stay in the institution, it was useful for them to choose employment involving a minimal risk of relapse. The risk of relapse was seen as higher in those cases where a patient returned to his original employment. The Tuchlov institution ceased to exist under circumstances very similar to those that applied to the treatment facility in Velké Kunčice. Its destiny was predetermined by the fact that it was situated in the Sudetenland, the area which, on the basis of the Munich Agreement, was handed over to the German Reich. No further details are known about the close-down of the institution. Considering its approach and the services offered to its patients, Tuchlov became a fully-fledged treatment facility which equalled the standards of alcohol institutions that operated in Western Europe, particularly in Switzerland and Germany (42).

Table 3. Number of patients in the Tuchlov institution from 1923 to 1930 , by nationality (45)

\begin{tabular}{|l|c|c|}
\hline Ser. No. & Nationality & Number of patients \\
\hline 1 & Czechoslovak & 151 \\
\hline 2 & German & 44 \\
\hline 3 & Russian & 4 \\
\hline 4 & Slovenian & 1 \\
\hline & Total & 200 \\
\hline
\end{tabular}

Hungarian Slovakia and the Period Preceding the Establishment of the Treatment Facility (1900-1937)

In terms of alcohol abuse, the situation in what is now Slovakia was different from the standards applied elsewhere in Central
Europe, including the development in the Czech lands. The initial treatment approaches to alcohol-dependent individuals in Slovakia were associated with the temperance movement and alcohol use-related education (prevention) dating back to the 1850s. The concerns about this issue and abstinence-oriented efforts resulted from social changes which occurred at the time and which were brought about by political and social developments in Slovakia. These changes in the approach to alcohol ensued from the activities of the Štúr Movement during the Slovak Revival and the representatives of the Roman Catholic Church becoming aware of the health and social consequences of the excessive consumption of alcohol, especially spirits. Significantly, it was in the mid-19th century that the major alcohol-related problems began to accumulate. Sedlák (44) described the social situation between 1844 and 1874 as very difficult: the population was tormented by subsistence problems, even famine, and many saw resorting to alcohol as the only solution.

In the Republic of Czechoslovakia, the first alcohol treatment institution, in Tuchlov, was established in 1923. This treatment facility also accepted patients from Slovakia, but its financial situation did not make it possible to meet the demand from all the patients, as a great number of them were not insured and the ministry was not willing to reimburse the treatment facility for all the patients. Pressure for the establishment of a treatment facility in Slovakia had been apparent since the independent republic was proclaimed in 1918. In this respect, the main driving element was the Czechoslovak Temperance Association (CTA), specifically its Regional Headquarters for Slovakia. The Statutes of the Regional Headquarters were endorsed by the Ministry in October 1925. Tomáš G. Masaryk was among its founding members and the Regional Headquarters also enjoyed support from Edvard Beneš.

Jurkovič (46) published the Teetotal Temperance Reader, summarising salient works by influential representatives of the anti-alcohol movement with regard to alcohol-related problems in Slovakia. The publication was primarily intended for district antialcohol boards and as reference material for awareness-raising lectures on alcohol. The secondary objective of the publication was to help in creating suitable conditions and obtaining financial resources for the establishment of the first alcohol treatment facility in Slovakia. The Orava region was chosen as a good place for the first alcohol institution in Slovakia. This location was identified as appropriate because it met important criteria for a treatment facility, including a quiet setting in the mountains, pastures, meadows, and forests in the surroundings, a town being not far away (Dolný Kubín), and a doctor, if needed, being within driving distance. It was decided that the treatment facility would be placed in a former church. The CTA procured the property from Anna Rakovszká in 1937. At the same time, the municipality of Istebné nad Oravou celebrated the 555th anniversary of its foundation, and to commemorate this anniversary (1937) it closed down its only pub. This was a totally unique constellation of circumstances.

\section{Istebné nad Oravou Institution (1937-1950)}

Founded by the Regional Headquarters for Slovakia of the Czechoslovak Temperance Association, the treatment institution in Istebné nad Oravou (Dolný Kubín District) was opened on 2 November 1937 at 10.30 . The establishment of the treatment facility resulted from efforts to provide treatment to those who 
"were deprived by alcoholism of their stamina, had their willpower broken and their enthusiasm for work subdued by alcohol and who were incapacitated for work, temporarily or for good, because of alcohol" (47). Approximately 250 people from Slovakia and the Czech lands, especially public figures, participated in the opening ceremony. The introductory speech was given by Dr. Ladislav Jurkovič, the CTA vice-chair for Slovakia. Financial contributions to the establishment of the treatment facility were made by the Ministry of Health, the Ministry of Welfare, and the Provincial Committee, headed by its president Jozef Országh. Personalities present at the formal opening included representatives of the regional and district authority, the Ministry of Health, Rudolf Homola, M.D., the district physician in Dolný Kubín, a priest on behalf of the Catholic Parish Office in Veličná, members of Matica Slovenská (a Slovak national cultural association), the mayor of Istebné nad Oravou, Father Bedřich Konařík on behalf of the Anti-alcohol Department, and members of the women's section of the Temperance Association.

The institution was intended for the treatment of alcoholics and cocaine and morphine addicts. It thus also catered to individuals with an addiction to substances other than alcohol, which made it different from both the Velké Kunčice and Tuchlov institutions. The capacity was set at 17 beds. Vladimír Fábry, M.D., from the Provincial Hospital in Dolný Kubín, was appointed as the inhouse physician. Emil Kraus was commissioned to manage the facility and provide pedagogical guidance. The treatment facility was administered by Ondrej Medvecký, who was involved in the operation of the institution until its close-down in 1949.

The daily fee for patients was 28 Czechoslovak crowns. The underprivileged were provided with a $25-50 \%$ discount, depending on their social circumstances. Those who were covered by health insurance offices and members of sickness funds had their stay fully covered in the same way as if they were admitted to a regular hospital. The duration of the residential treatment was set at 5-6 months. Financial support was also received from local government, especially from the Dolný Kubín District Authority; in 1938, for example, such a contribution amounted to 3,000 crowns (47).

During its operation, the treatment facility faced technical problems: the water pipes froze in the winter and water had to be carried from a well, the bathroom and the hydrotherapy room were not equipped sufficiently (hydrotherapy could not be provided to the extent originally intended, and the toilets were "primitive, with no flushing"). The physical conditions improved significantly in November 1938. To this day, the time of the dissolution of the institution cannot be determined exactly. The literature generally suggests that the treatment facility closed down in April 1939 (48). On 30 September 1948, patient, a postal worker, applied for admission to treatment (49) and in November 1948 correspondence was exchanged between the institution and the Health Commission concerning the endorsement of a certificate needed for the issue of food vouchers and instructions regarding construction works (50). At that time the alcohol institution was incorporated into the national health system (51). On paper, in the first half of 1949 the treatment facility was still in operation. Practically, the treatment facility was closed down in December 1949. The last employment contract was terminated as of 1 October 1949 (52). On Monday 5 December 1949, the caretaker of the institution advised the Health Commission in writing of an amount needed to repair damaged railing (53), and on Thursday 8 December 1949, a record of the inventory of the former teetotal institution in Istebné was made, under the institutional reference number 117/1949 (54).

By January 1950 the former church housed the Regional Children's Home (55).

\section{DISCUSSION}

This paper analyses the origin and development of institutional alcohol treatment in the historical area of what was then, or was later to become, Czechoslovakia in the period from 1900 to 1949. The analysis involved archival investigation of historical sources, using multiple case studies.

Prevention programmes did not attract greater attention until they became institutionalised, i.e. until the implementation of prevention activities had moved to specialised alcohol treatment facilities. According to the available evidence, such activities date back to the 1850 s.

By the end of the century the term "alcoholism" had been defined, referring to excessive drinking (8) and, as a new element, a conceptual distinction had been drawn between harmful and addictive drinking with consequences on the one hand and occasional alcohol use on the other hand. No strict boundaries between types of addiction had been determined at the time, as no statistics and data about alcohol-related mortality and morbidity were available.

The growing importance of treatment processes was accompanied by procedural changes in institutional treatment, including its orientation, e.g. open- vs. closed-door approaches. As for European regions, there, too, institutionalised establishments offering residential treatment came into being at the end of the 19th century, with their development and orientation being determined by either temperance societies or the US experience. The investigation of the geographical relationships between countries, or regions, indicates that the potential differences in the developments in neighbouring countries may have been due to factors related to political and legal aspects.

While in the Czech lands anti-alcohol initiatives predominantly concerned beer and wine, and spirits less so, in Slovakia, conversely, the main emphasis was placed on spirits. This differentiation could have had a negative impact on the development of the temperance movement in what is now the Czech Republic, given the enduring myths about the nutritional quality of beer. Despite the efforts of a number of experts, such as Delbrück (14), to refute this myth, the dissemination of scientific evidence at the time was insufficient and difficult to achieve in practical terms.

The early 19th century saw a rise in the number of scholarly publications on alcohol; there were even some degree theses. First and foremost, they sought to have an educational impact, to inform the public about the harmful effects of alcoholism not only on drinkers, but also on their social environment, family, and community, hereditary health conditions passed on to offspring, medical implications for individuals from the early stages of life, and other adverse consequences. The establishment of dedicated associations (e.g. the Provincial Association against Alcoholism in the Kingdom of Bohemia) had an even greater influence on changes in the perception of the negative implications of alcoholism at the time. Among other things, their activities resulted in the issue of alcoholism attracting the attention of a growing range of people, including politicians, lending it a formal dimension of 
the protection of public health. This led to the issue being viewed from a broader perspective, where, in addition to efforts to eliminate alcohol addiction, prevention concepts came to the fore and began to be reflected in school curricula and the establishment of alcohol-free pubs, restaurants, and hotels.

Dealing in bottled beer also became viewed as problematic and was therefore subjected to restrictions. This can be considered significant progress in the way the population perceived the harms of alcohol at the time, although, because of limited data, it is difficult to quantify its degree. Besides the commodity dimension, the development of alcohol-related prevention processes had implications for various population groups, and not only in terms of age categories. Specific proposals for prevention programmes for schoolchildren, the workforce (involving restrictions on the purchase of alcohol on paydays), and for soldiers and mariners were introduced. The tendencies described above indicate that during the 19th century alcohol-related issues grew in importance and became institutionalised.

The archival evidence makes it problematic to draw conclusions about any homogenous nature of the development of antialcohol processes in different European countries. Equally, it is problematic to investigate similarities in developmental processes across neighbouring countries and look for any correlates, as the developments in these countries were determined by a range of geopolitical factors, the availability of alcohol in each country, and the efforts of enthusiastic advocates and prominent representatives of medical or other professional communities engaging in awareness-raising activities.

Historical case studies may be of great value, as they provide a detailed account of each stage of the development of national anti-alcohol activities, as well as being indicative of their determinants and the stakeholders involved.

The processes of the building of major treatment facilities in what was, or was later to become, Czechoslovakia were greatly facilitated by the experience of those individuals, including P. Bedřich Konařík, Jan Šimsa, Břetislav Foustka, and Karol Lányi, who devoted significant parts of their lives to anti-alcohol efforts and helped transform them into professional activities.

\section{CONCLUSIONS}

Both the case studies and historical development indicate a marked shift from the notion of beneficial alcohol use towards the perception of its multidimensional harmful effects. The understanding of historical correlates identified by the present study by providing a historical outline of the activities pursued by three treatment facilities in today's Czech Republic and Slovakia makes it possible to explore comprehensive aspects of development, socioeconomic trajectories, and the degree to which foreign influences and experience were incorporated into the organisational and procedural structures of treatment facilities, which became the main promoters of prevention and perception of the harmful effects of alcohol on individuals and society as a whole.

\section{Conflict of Interests}

None declared

\section{Grant Support}

Institutional support was provided by the Grant Agency of Charles University, First faculty of Medicine under the project GA UK 1290218 and by Charles University, Progress Programme No. Q06/LF1.

\section{REFERENCES}

1. Šejvl J, Barták M. Počátky ústavní léčby závislosti na alkoholu v českých zemích na počátku 20. století $\mathrm{v}$ kontextu veřejného zdravotnictví [The beginnings of the institutional treatment of alcohol dependence on Czech territory in the early 20 th century in the context of public health]. Adiktologie. 2017;17(4):272-80.

2. Harris J. Cultural aspects: representations of alcohol use in visual art. In: Boyle P, editor. Alcohol: science, policy and public health. Part I. Framing the issues. Oxford: Oxford University Press; 2013. p. 24.

3. Ashley MJ, Rankin JG. A public health approach to the prevention of alcohol-related health problems. Annu Rev Public Health. 1988;9:233-71.

4. Edwards G. Alcohol, the ambiguos molecule. London: Penguin Books; 2000.

5. Rush B. An Inquiry into the effects of ardent spirits on the human body and mind, with an account of the means for preventing and of the remedies for curing them. New York: Cornelius Davis; 1811.

6. Trotter T. An essay, medical, philosophical, and chemical, on drunkenness, and its effects on the human body. London: T. N. Longman and G. Rees; 1804.

7. Huss M. Alcoholismus chronicus, or chronic alcoholism: contribution to the understanding of dyscrasias according to their own experience and that of others. Stockholm: Joh. Beckman; 1849-1851.

8. Sournia JC. L'Histoire de l'alcoholisme. Paris: Flammarion; 1986.

9. Room R, Babor T, Rehm J. Alcohol and public health. Lancet. 2005;365(9458):519-30.

10. Room R. Alcohol control and public health. Annual Rev Public Health. 1984;5(1):293-317.

11. Skála J. Alkoholismus [Alcoholism]. Prague: Státní zdravotnické nakladatelství [State Health Publishing House]; 1957.

12. Konařík B. Asyly pro pijáky [Drinkers' asylums]. Prostějov: Křřžový spolek [Cross Association].

13. Duka Zólyomi N. Problém alkoholu a alkoholizmu v slovenskej literatúre XXV. Hnutie Modrého kríža na Slovensku [The Problem of alcohol and alcoholism in Slovak literature XXV. Blue Cross Movement in Slovakia]. Protialkohoický obzor. 1981:175-84.

14. Delbrück A. Hygiene des Alkoholismus. In: Weyl T, Herausgeber. Handbuch der Hygiene. Supplementband 1. Jena: G. Fischer; 1901. S. 113-95.

15. Masaryk TG. O ethice a alkoholismu [On ethics and alcoholism]. Prague: Klíčník; 1912.

16. Pjseň nowá o vžitku nepokogné kořalky w nowě na swětlo wydaná, Wytisstěná nyněgssjho roku [A New song about restless fire-water brought to light again, printed this year] (by an anonymous writer, early 19 th century).

17. Rampel E. Abhandlung von dem Laster der Trunkenheit. Brünn; 1812.

18. Poučenj o pitj kořalky. Podlé německého sepsáno, a ku prospěchu národu českoslowanského w Čechách, w Morawě a Uhřjch [Advice on drinking spirits written according to the German original and brought to light for the benefit of the Czechoslovak nation in Bohemia, Moravia, and Hungary]. Prague: Jan Spurný; 1838.

19. Sorger F. Conspectus, sistens observationes circa delirium cum tremore potatorum anno 1837 et priore semestri 1838 in clinico medico Pragensi sub auspiciis dom. prof. W.F. Rilke factas: dissertatio inauguralis medica: quam consensu et auctoritate perillustris, celeberrimi ... Pragae; 1838.

20. Zschokke H. Kořalečnj mor, aneb Kratochwilné poučenj, proč a gak se člowěk pitj kořalky warowati má [The liquor plague, or an amusing note on why a person should stay away from liquor]. Prague: Jan Spurný; 1840.

21. Spurný I. Následkowé pitj kořalky s připogenjm některých ponaučenj pro lid wenkowský [Consequences of drinking liquor with some advice for country people attached]. Holomauc: A. Skarnitzl; 1840.

22. Procházka JG. Dissertatio inauguralis medica de morbis potatorum: quam consensu et auctoritate perillustris, celeberrimi ac magnifici ... Pragae; 1842.

23. Pantůček F. Report to the Provincial Congress. Prague; 1905.

24. Foustka B. Slabí v lidské společnosti: ideály humanitní a degenerace národů [The Weak in human society: humanitarian ideals and the degeneration of nations]. Prague: Jan Laichter in Královské Vinohrady; 1904. 
25. Barth J. Protialkoholní hlídka [Anti-alcohol sentinel]. Nová kultura. 1912-1913;6-7:19.

26. Miovský M. Kvalitativní přístup a metody v psychologickém výzkumu [Qualitative approach and methods in psychological research]. Prague: Grada Publishing; 2006.

27. Plichtová J. Obsahová analýza a jej možnosti využitia v psychológii [Content analysis and the possibilities of its use in psychology]. Cesk Psychol. 1996;40(4):304-14.

28. Miles MB, Huberman AM. Qualitative data analysis: an expanded sourcebook. London: SAGE Publications; 1994.

29. Strauss A, Corbin JM. Grounded theory in practice. London: SAGE; 1997.

30. Konařík B. Léčebna pro alkoholiky [Alcoholic institution]. Prostějov: Prostějovský odbor Českoslovanského abstinentního svazu a Stř́idmostní spolek mládeže mužské Jablonský [Prostějov Office of the Czechoslovak Temperance Association and the Jablonský Temperance Union]; 1908.

31. Konařík B. Boj proti alkoholismu a jeho léčení v zemích protestantských [Fighting alcoholism and its treatment in Protestant countries]. Prostějov: Kř́̌žový spolek [Cross Association]; 1910.

32. Konař́k B. Bude Ellikon též na Moravě? [Will there also be an Ellikon in Moravia?]. Zdravotnické rozhledy. 1908;6(7-8):100.

33. Konařík B, Halenka V. Zevrubná zpráva o dosavadních krocích ke zřízení léčebny." [A comprehensive report on the steps taken hitherto towards the establishment of a treatment facility]. Prostějov, 30 June 1910.

34. Kubela R. Literární odkaz Bedřicha Konaříka-Bečvana [Literary legacy of Bedřich Konařík - Bečvan]. Zpravodaj Okresního vlastivědného muzea ve Vsetíně [Newsletter of the District Museum of National History in Vsetín]. 1990 Aug:42-3.

35. Šejvl J, Miovský M. Nejstarší specializované lůžkové zařízení pro léčbu závislosti na alkoholu na historickém území Čech a Moravy: př́ípadová studie protialkoholní léčebny ve Velkých Kunčicích (1911-1915) [The first specialised residential treatment institution and programme for alcohol-related problems in the historical area of Bohemia and Moravia: case study of the residential alcohol programme in Velké Kunčice (19111915)]. Adiktologie. 2017;17(2):134-46.

36. Forster V. Duševní poruchy a jich léčení - psychopatologie a psychoterapie [Mental disorders and their treatment - psychopathology and psychotherapy]. Prague: Gustav Voleský, a bookseller in Královské Vinohrady; 1926.

37. Konařík B. Léčení alkoholismu v cizině a u nás [Treatment of alcoholism abroad and at home]. Prague: Československý abstinentní svaz [Czechoslovak Temperance Association]; 1934.

38. National Central Archives. CTA. Statutes of the Czech Temperance Association. Ref. no. 367. Call no. 1367. 1922

39. Barth J. Abstinentní pensionát Tuchlov [Teetotal Boarding House Tuchlov]. Nová kultura. 1923;12:206-7.

40. Šimsa J. et al. Přírodní léčba a domácí lékař [Natural treatment and a home doctor]. Prague: F. Strnadel a spol.; 1923.

41. Vondráček V, Klášterský I. Farmakologie duše [Pharmacology of the soul]. Prague: Mladá generace lékařů při Ústřední jednotě čs. lékařů [Young Generation of Physicians at the Central Union of Czechoslovak Physicians]; 1935.

42. Šejvl J, Miovský M. The First inpatient alcohol treatment facility in the Czech Republic: case study of the Tuchlov institution (1923-1938). Adiktologie. 2018;18(2):97-104.

43. Konařík B. Jak odvykáme pití lihovin. [Giving up drinking]. Zdraví lidu. 1936;14(5):65-8.
44. Sedlák P. Hnutie spolkov striezlivosti na Slovensku v rokoch 1844-1874 [Movement of temperance associations in Slovakia from 1844 to 1874]. Prešov: Michal Vašek Pablishers; 1998.

45. Konařík, B. Proč nebyl vždy Tuchlov plně obsazen [Why did Tuchlov not always reach full occupancy]. Prague: National Museum Archives

46. Jurkovič L, Čárský J, Čobrdu PV, Matzenauer J, Vlasák G, Procházka A. Abstinentná protialkoholná ćítanka [Teetotal temperance reader]. Bratislava: Krajinské ústredie pro Slovensko Čsl. abstinentného sväzu [Regional Headquarters for Slovakia, Czechoslovak Temperance Association]; 1935

47. Krajinské ústredie pre Slovensko Čsl. Abstinentného sväzu v Bratislave - odporúčanie abstinentnej liečebne; ze dne 16. nov. 1937, č.j.: 1399/37 [Regional Headquarters for Slovakia, Czechoslovak Temperance Association - recommendation to the teetotal treatment facility; dated 16 November 1937. Ref. no. 1399/37]. Dolný Kubín District Archives. Call no. 137.1937.

48. Morovicsová E, Falisová A. Význam protialkoholických liečební v boji proti alkoholizmu v prvej Československej republike [The Importance of anti-alcohol treatment institutions for the fight against alcoholism in the first Czechoslovak Republic]. Ceska Slov Psychiatr. 2016;112(6):287-97.

49. Treatment application. Pavol Roháček - pošt. zriadenec-žiadost' o liečbu zo dňa 30. 9. 1948. [Pavol Roháček - a postal worker - application for treatment dated 30 September 1948]. Dolný Kubín District Archives. Call no. 137. 1948.

50. Health Commission. Liečebný ústav v Istebnom nad Oravou - opravné práce; ze dne 6. 11. 1948, č.j. 224-17455/1948 [Treatment institution in Istebné nad Oravou - repair works; dated 6 November 1948. Ref. no. 224-17455/1948]. Dolný Kubín District Archives. Call no. 137. 1948.

51. Consumption receipt. Počítací stroj zn. Albona, Štátny liečebný ústav pre alkoholikov v Istebnom n/Or., zo dňa 17. 11. 1948, č.j. 57/1948 [Calculating machine Albona, National Alcohol Treatment Institution in Istebné nad Oravou, dated 17 November 1948. Ref. no. 57/1948]. Dolný Kubín District Archives. Call no. 137. 1948.

52. Overpayment. Andrej Medvecký, bývalý domovník ústavu v Istebnom n/O, preplatok, zo dňa 16. 4. 1950, č.j. 141-23061/1949. [Andrej Medvecký, a former caretaker of the institution in Istebné nad Oravou, overpayment; dated 16 April 1950. Ref. no. 141-23061/1949]. Dolný Kubín District Archives. Call no. 137. 1950.

53. Damaged railing. Dopis Štátneho liečebného ústavu pre alkoholikov v Istebnom n/Oravou Povereníctvu zdravotníctva ohladne poškodeného zábradlia, zo dňa 5. 12. 1949, č.j. 111/1949. [A letter from the National Alcohol Treatment Institution in Istebné nad Oravou to the Health Commission concerning damaged railing, dated 5 December 1949. Ref. no. 111/1949]. Dolný Kubín District Archives. Call No. 137. 1949.

54. Items of inventory. Odpis zápisnice o inventári bývalej abst. liečebne v Istebnom, zo dňa 8. 12. 1949, č.j. 117/1949 [Copy of the record of the inventory of the former teetotal institution in Istebné, dated 8 December 1949. Ref. no. 117/1949]. Dolný Kubín District Archives. No call number. 1949.

55. A bill for the Regional Children's Home in Istebné nad Oravou, dated 9 January 1950, without a reference number. Dolný Kubín District Archives. Call no. 137. 1950. 